\title{
Phonology-Based Instruction for Pre-Literacy Japanese Elementary Students
}

\section{Naomi Watanabe \\ Higashi Elementary School, Tsukuba}

\section{Reference Data}

Watanabe, N. (2021). Phonology-based Instruction for Pre-literacy Japanese elementary students. In P. Clements, R. Derrah, \& P. Ferguson (Eds.), Communities of teachers \& learners. JALT. https:// doi.org/10.37546/JALTPCP2020-13

This study investigated the following three points regarding the effectiveness of phonology-based instruction on Japanese elementary school students. (1) Does phonology-based instruction have positive effects on improving phonological awareness in Japanese elementary school students?; (2) To what extent does phonology-based instruction enhance letter knowledge in Japanese elementary school students?; and (3) Does phonology-based instruction motivate Japanese elementary school students to learn English? Twenty-nine fourth graders in a public elementary school received phonology-based instruction, such as reciting and singing along with nursery rhymes, detecting rhymes or initial phonemes, and counting syllables. These activities took place during weekly 15-minute modules in English classes. Additionally, letter activities were conducted in English and other subjects to help develop phonological awareness. Study results suggested that phonology-based instruction was effective in improving students' phonological awareness and attitudes to learn English.

本研究は、日本の小学生に対する音韻指導の有効性について、以下の3点について調べたものである。(1) 日本の小学生の 音韻認識の向上にプラスの効果があるか。(2) 日本の小学生の文字知識をどの程度向上させるか。(3) 日本の小学生が英語を 学ぶことへの動機付けとなるか。参加者は、公立小学校の4年生29名で、ナーサリーライムの暗唱や歌唱、脚䫓や最初の音素 の気付き、音節の数などの音韻指導を受けた。これらの活動は、每週の英語の授業で15分の帯活動で実施され、さらに、音韻 認識の発達を促進するために英語および他の教科で文字の活動が行われた。結果として音韻指導が小学生の音韻認識と英 語学習に対する態度を向上するのに効果的であることが示唆された。
Jnder the current elementary school curriculum guidelines issued by the Ministry of Education, Culture, Sports, Science and Technology (MEXT) in 2017, the instruction of reading and writing in English officially starts in fifth and sixth grades of elementary school. Before literacy training, there should be the introduction and development of pre-literacy skills. Phonological awareness is one of the key foundations of literacy development, which begins long before formal school education begins (Yopp \& Yopp, 2011). However, it is difficult for most Japanese elementary school students to independently develop English phonological awareness. It is necessary for schools to provide guidance to cultivate the development of phonological awareness in the third and fourth grades. In addition, students during this period are entering a stage of life in which logic and reason are applied to learning (Inhelder \& Piaget, 1958). This would be an ideal time for students to be able to analytically notice the phonological features of English.

This study aims to investigate the effectiveness of phonology-based instruction in developing phonological awareness in preliterate Japanese elementary school students. In other words, it evaluates the teachability and learnability of phonological awareness with explicit phonology-based instruction. In addition, this study is an extension of the author's masters thesis, which was in the 2019 Japanese academic year.

\section{Theoretical Background}

Phonological Awareness

Phonological awareness is often defined as sensitivity to the sound structure of spoken words (Stahl \& Murray, 1994; Yopp \& Yopp, 2009). Phonological awareness plays a critical role in successful reading in English speaking countries. Gillon (2018) classified phonological skills into three levels according to their complexity: syllables, onsets and rimes, and phonemes. A phoneme is the smallest unit of sound that affects the meaning of a word. 
JALT2020

COMMUNITIES OF
TEACHERS \& LEARNERS

\section{English as a First Language Context}

In the UK, MacLean, Bryant, and Bradley (1987) found that there is a strong and lasting relationship between nursery rhyme knowledge and phonological awareness. The nursery rhyme knowledge is associated with the development of phonological awareness and is linked to the children's success in literacy. They emphasized that there is a stronger correlation than when comparing children's IQs or family backgrounds.

In the US, the National Reading Panel (2000) reported the effectiveness of phonemic awareness training for future literacy regardless of socio-economic background. The report also stated phonemic awareness instruction should precede phonics instruction as sometimes phonological awareness is confused with phonics. To clarify, phonics refer to teaching the correspondence between sounds and letters for reading and spelling. Ehri et al. (2001) analyzed the National Reading Panel Report and concluded that phonological awareness and letter knowledge instruction are crucial in alphabetic languages.

\section{Japanese English as a Foreign Language (EFL) Context}

Although teaching phonological awareness is effective in English speaking countries, there is still scope to investigate the effectiveness of teaching phonological awareness in an English as a Foreign Language (EFL) context. Allen-Tamai (1999, 2006, 2008, $2009, \& 2010$ ) has conducted dozens of studies on phonological awareness in Japan. In her studies, she emphasized the effectiveness of phonological awareness instruction including teaching letter knowledge for Japanese young learners' literacy.

Ikeda (2015) noted there are multiple levels in phonological awareness, and some of them are difficult for Japanese children to develop on their own. Therefore, young learners in Japan need explicit instruction based on phonology.

\section{Research Questions}

Based on these implications, this study investigates the efficacy of explicit phonologybased instruction on Japanese EFL elementary school students. If the present study can set a precedent for teaching phonological awareness, it may help future research in this area. The research was organized around the following research questions:

RQ1. Does phonology-based instruction have positive effects on improving phonological awareness in Japanese elementary school students?

RQ2. To what extent does phonology-based instruction enhance letter knowledge in Japanese elementary school students?
RQ3. Does phonology-based instruction motivate Japanese elementary school students to learn English?

\section{Method}

Participants

All participants in the study gave informed consent to the researcher, and the project was cleared with the school's institutional review board.

The participants were 29 fourth graders of a public elementary school in lbaraki prefecture, Japan. They were the author's home room class students. Once a week, they learned English in a "Foreign Language Activity." Half of them had never learned English outside of school, though ten percent had been learning English for more than five years (see Figure 1). At school, in Japanese class, they only learned how to read upper and lowercase letters, as well as romaji (system of Romanized spelling). They had not learned how to read English words in English classes, meaning they were pre-literate.

Figure 1

Students' Experience of Learning English

o Less than I year

1 to 3 years

more than 4 years

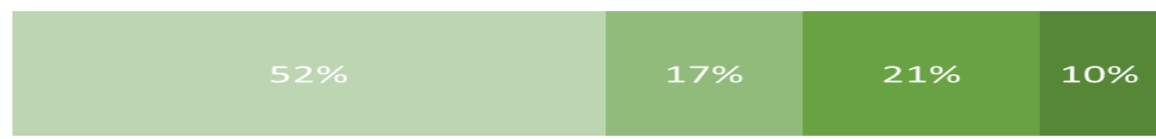

$0 \%$ $20 \%$ $40 \%$

$60 \%$

$80 \%$ $100 \%$

\section{Procedure}

The lessons were conducted by the author of this study and the Assistant Language Teacher (ALT) in two types of settings: informal teaching and 15-minute module lessons in a structured program. Just before class started, informal teaching was given during the session held every morning. The students received phonology-based instruction, including sound activities and letter knowledge activities from April 2019 to February 
2020 (during the Japanese academic year). Some lessons in March were cancelled due to Covid-19. Table 1 shows the general schedule of the phonology-based instruction and assessment including follow-up interviews.

Table 1

Schedule of Phonology-Based Instruction and Assessment

\begin{tabular}{|c|c|c|c|c|}
\hline \multirow[t]{2}{*}{ Setting } & \multicolumn{2}{|c|}{ Informal Teaching } & \multicolumn{2}{|c|}{ Structured Program } \\
\hline & \multicolumn{2}{|c|}{ Morning Session } & 15-minute Module & Cross-curriculum \\
\hline$T_{u}$ & \multicolumn{3}{|c|}{ Sound Activities } & itio \\
\hline Apr. & \multicolumn{4}{|c|}{ Pretests \& Pre-course Questionnaire } \\
\hline May & \multirow{5}{*}{$\begin{array}{l}\text { Rhyme Time } 1 \\
\text { (Recitation) }\end{array}$} & \multirow{3}{*}{\multicolumn{2}{|c|}{$\begin{array}{l}\text { - Key Sound Game } \\
\text { - Key Rhyme Game }\end{array}$}} & \\
\hline June & & & & Letter Knowledge \\
\hline July & & & & Romaji \\
\hline Sept. & & \multirow{6}{*}{\multicolumn{2}{|c|}{$\begin{array}{l}\text { - How Many Beats? } \\
\text { - Snail Talk } \\
\text { (Key Sound Game } \\
\text { \& Key Rhyme Game) }\end{array}$}} & Romaji \\
\hline Oct. & & & & Posttests \\
\hline Nov. & \multirow{4}{*}{$\begin{array}{c}\text { Rhyme Time } 2 \\
\text { (Singing along } \\
\text { with) }\end{array}$} & & & \\
\hline Dec. & & & & \\
\hline Jan. & & & & \\
\hline Feb. & & & & \\
\hline Mar. & \multicolumn{3}{|c|}{$\begin{array}{l}\text { Posttest, Post-course Questionnaire, \& Follow-up } \\
\text { Interviews }\end{array}$} & Delayed Posttests \\
\hline
\end{tabular}

Phonology-Based Instruction

Year-Round Sound Activity

During the entire session, the students took part in "Rhyme Time." The aim of this activity was to expose students to nursery rhymes. In order to create the exposure, the activity was implemented in a 15-minute module during every English class, and for 2-3 minutes in the daily morning session. The syllabus was divided into two parts: recitation and singing. Every two weeks, a new nursery rhyme was introduced. Students experienced 11 nursery rhymes throughout the school year (see Table 2).

Table 2

Nursery Rhymes for Rhyme Time

\begin{tabular}{|c|c|c|}
\hline Recitation & Singing Along With & Nursery Rhymes \\
\hline \multirow{2}{*}{ April } & October & Baa Baa Black Sheep \\
\hline & \multirow{2}{*}{ November } & Rain Rain Go Away \\
\hline \multirow{2}{*}{ May } & & Hey Diddle Diddle \\
\hline & \multirow{2}{*}{ December } & Twinkle Twinkle Little Star \\
\hline \multirow{2}{*}{ June } & & Humpty Dumpty \\
\hline & \multirow{2}{*}{ January } & Jack and Jill \\
\hline \multirow{2}{*}{ July } & & Hickory Dickory Dock \\
\hline & \multirow{2}{*}{ February } & Itsy Bitsy Spider \\
\hline \multirow{2}{*}{ September } & & Row, Row, Row Your Boat \\
\hline & \multirow{2}{*}{$\begin{array}{c}\text { March } \\
\text { *cancelled due to Covid-19 }\end{array}$} & Teddy Bear Teddy Bear \\
\hline October & & Five Little Monkeys \\
\hline
\end{tabular}

First Round Sound Activities from April to July

The first round of sound activities were implemented from April to July. During the session, the two activities introduced by Allen-Tamai (2019) were carried out to raise the students' awareness of the structure of the word onset-rime. The first activity was called "key sound" game. It focused on the onset sound of a word consonant. In this activity, paired students tried to distinguish whether the words they heard were the same as the target sound or not. There was an eraser set in front of each pair. When they noticed that the word did not start with the target sound, the students rushed to be the first one to grab the eraser. The one who grabbed it first, won. For example, the target sound was /d / and the teacher said "dog, desk, deck". If the students heard a word that did not start with / d /, such as "pot", they should have grabbed the eraser.

The second activity was a cooperative pair work called the "key rhyme" game. It encouraged the students to notice the endings of words. In this activity, the teacher 
read out several words ending with the same key rhyme. The paired students did a "high ten" if they noticed the ending rhyme of the word was different from the key rhyme. For example, the key rhyme was /et/, and the students heard "met, pet, set, men." When the students heard "men," they had to do a "high ten."

\section{Second Round Sound Activities from September to February}

The author introduced new sound activities in September as the students became accustomed to the first and last sounds of English words through the first round. "Snail Talk" was adapted from Chard and Dickson (1999). The activity explicitly aimed to teach phonemes to the students. After playing the key sound game and the key rhyme game, the author repeated each phoneme of some words in the vocabulary used in those games like "bbbb/iiii/gggg." Then, the students tried to blend the sounds into a word b/i/g "big." Elkonin boxes were also shown as a visual aid (see Appendix A).

Another activity was called "How Many Beats?" It aimed at helping the students notice syllables. The students clapped their hands as many times as the number of beats they felt the word had. After the students demonstrated the number using their fingers, the correct number was indicated with a clear pronunciation of the same word.

Letter Activities from Late June to July and September to October

Nation (2009) suggests that letter knowledge supports the development of phonological awareness. The students were given various letter instruction as crosscurriculum in late June to July.

Letter Activities in Foreign Language Activities Classes

The first activity was "Pointing Game," which was introduced in MEXT's (2017) course book to instruct students in letter names and shapes. In this activity, the students pointed to the letter by listening. As "b and v" are one of the most difficult pairs for Japanese students to distinguish, the author added a special activity for this pair using American Sign Language (ASL). The students heard "b" or " $\mathrm{v}$ " with their eyes closed, and answered using ASL. Gradually, the students became able to distinguish the two letter sounds.

After the pointing game, the students tried the "I Spy Game." This game starts with the typical phrase "I spy with my little eye," and provides some hints to the participants on what letters are in it. A quiz leader and the students see the same page of the course book filled with pictures of many collages. During the game, students had to listen well to find objects hiding in a particular collage. Therefore, the students could facilitate their letter knowledge while enjoying the game. Because the students' grammar knowledge was limited, the author combined the I Spy Game with the "Who am I?" quiz. For example, initially students say, "I spy with my little eye" and pick one collage. Then, they do the "Who am I?" quiz, saying "I have an 'a.' I have a 't.' I have four letters. Who am I?" During this activity, a visual aid called "English Map" was used to encourage students to speak up (see Appendix B). As all the students knew the famous book series, "I Spy" "Mikke" in Japanese), the students were able to pick up the rules quickly. Through the five lessons of the unit, students did this activity repeatedly, and they created their own "I Spy" quiz, using their names in the end.

\section{Letter Activities in Cross Curriculum}

Some letter activities were conducted in art classes. The students colored the letters in their art work when they made one page of a picture book inspired by "Brown Bear, Brown Bear, What Do You See?” by Bill Martin, Jr. and Eric Carle. This activity aimed at giving them exposure and experience, writing in English. Though it was too difficult for the fourth graders to write a sentence in English, they were able to enjoy coloring the letters in the sentence (see Figure 2). In another art class, the students wrote their signature on their art works. The author told the students that a painter would sign his or her work, thus making it meaningful for the students to write their name just like an artist (see Figure 3).

Figure 2

Coloring the Letters

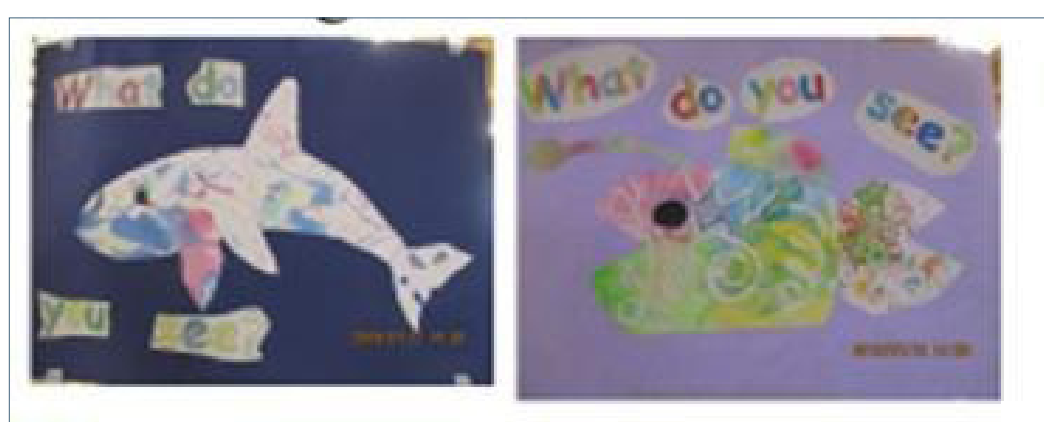


JALT2020

COMMUNITIES OF
TEACHERS \& IEARNERS

Figure 3

Signatures on Artwork

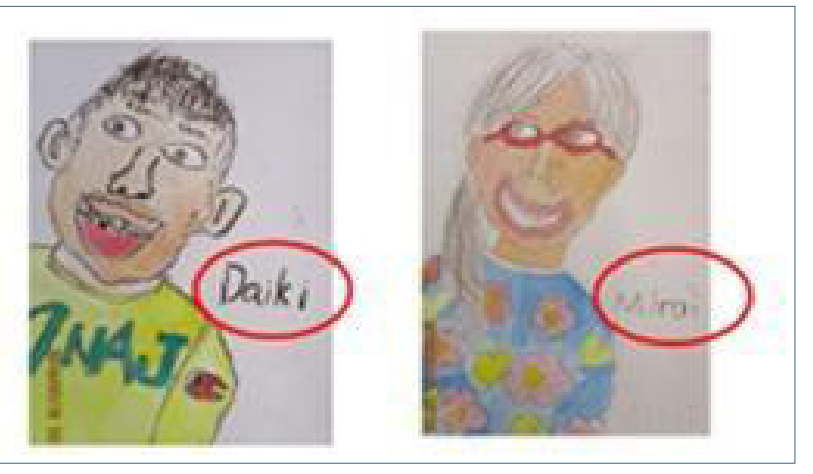

The author included some letter activities in Japanese and Social Studies classes.

Murakami (2019) suggested the concept that multisensory activities, such as using Playdough, were effective for learning letters. In the beginning, the author used Play-dough to create and display lowercase letters to show students the shape of the letters. Then, in July, the students formed lowercase letters and their names. After the summer holidays, the students formed prefecture names concurrently while learning about them in Social Studies. Using Play-dough worked well for students' understanding of not only letter shapes, but also how to write letters (i.e., pre-writing skills).

Figure 4

Name Writing with Playdough

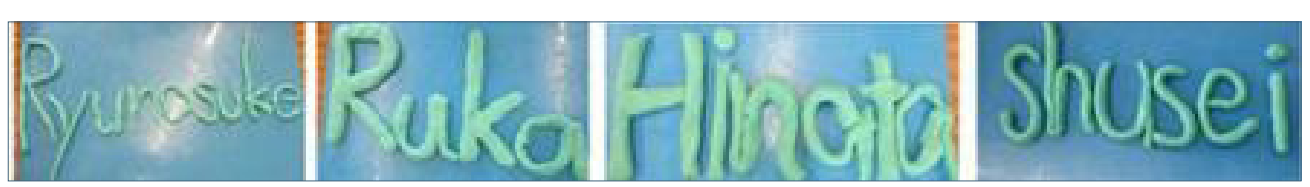

\section{Assessment and Questionnaire}

In order to measure the development in students' ability related to phonological awareness, three tests were administered before and after the intervention: sound categorization, letter name-knowledge, and name writing. The latter two tests were administered in October as posttests when the letter intervention finished, and delayed posttests were also administered in March. Additionally, information was collected on the students' attitude toward English learning before and after the course.

\section{Sound Categorization Test}

This test was administered before and after phonological instruction in order to measure the students' improvement in their perception associated with phonological recognition. The pretest was conducted in April and the posttest was conducted in February in the regular classroom using a projector with a built-in speaker. The sound categorization test, adapted from Kirtley et al. (1989) and Ikeda (2015), consisted of three sound categorization tasks: initial, middle, and end-sound of words.

\section{Letter Name Knowledge Tests}

As mentioned earlier, this test was conducted three times as a delayed posttest in addition to the pre and posttest. It aimed to test the students' knowledge of the shapes and names of letters. In the tests, the students listened to 20 letter names one by one, and tried to find the correct letter out of five options. This test was adapted from Ikeda (2015).

\section{Name Writing Tests}

This test was also administered three times as pre, post, and delayed posttests. In order to evaluate students' name writing skills in Hepburn romaji, the students were asked to write his or her first and family name in Hepburn romaji. Name writing skills were scored based on a five-point scale developed by the author. Scores were awarded as follows:

- 0 for no response;

- 1 for a correct initial letter;

- 1 for correct capitalization;

- 1 for a correct letter except for an initial;

- 1 for correct spacing, and;

- 5 for correct spelling. 
JALT2020

COMMUNITIES OF
TEACHERS \& IEARNERS

Watanabe: Phonology-Based Instruction for Pre-Literacy Japanese Elementary Students

\section{Results and Discussion}

Effects of Phonology-Based Instruction on the Students' Phonological Awareness

Regarding research question 1 , the students showed improvement in their phonological awareness. Figure 5 shows that the correct response rate increased from $48.8 \%$ to $66.9 \%$. The difference between results of pre and posttests was statistically significant $(p<.001)$. Some students remarkably improved their sound awareness. One girl's score went from $17.5 \%$ to $50 \%$. Her comment on sound activities was that she enjoyed listening to English and playing the games. Having fun is one of the key priority for elementary school students.

Figure 6 shows the phonemes or rimes with the low correct response rates. This information revealed the phonological challenges for these Japanese elementary school students. The author found that the students were poor at distinguishing between diphthongs and short vowels such as /ei/ and /e/. This is thought to be influenced by the Japanese mora (the basic phoneme unit in Japanese). The set of words with the lowest correct response rate was "tip," "top," and "lip." The students had to distinguish between /ip/ and /op/. In this case, many students chose "lip" as the first two words beginning with $/ \mathrm{t} /$. This was the result of the absence of onset-rime awareness which the British preschoolers had in the study of Kirtley et al. (1989). These findings and subsequent analyses suggest that onset-rime awareness could be useful if taught to Japanese children.

Figure 5

Correct Response Rates of Sound Categorization

\begin{tabular}{|c|c|c|}
\hline $100.00 \%$ & & \\
\hline $80.00 \%$ & & \\
\hline $60.00 \%$ & & $66.90 \%$ \\
\hline $40.00 \%$ & $48.79 \%$ & \\
\hline $20.00 \%$ & & \\
\hline $0.00 \%$ & & \\
\hline & April & March \\
\hline
\end{tabular}

Figure 6

Sounds with Low Correct Response Rate

\begin{tabular}{|c|c|c|}
\hline \multicolumn{3}{|l|}{$100.00 \%$} \\
\hline \multicolumn{3}{|l|}{$80.00 \%$} \\
\hline \multicolumn{3}{|l|}{$60.00 \%$} \\
\hline $40.00 \%$ & \multirow{2}{*}{\multicolumn{2}{|c|}{$27.59 \%-24.18 \%$}} \\
\hline $20.00 \%$ & & \\
\hline \multirow{2}{*}{$0.00 \%$} & & $20.69 \%$ \\
\hline & April & March \\
\hline & æ/ - & op/ /ip/ \\
\hline
\end{tabular}

Effects of Phonology-Based Instruction on the Students' Letter Knowledge

Regarding the research question 2 , the students showed improvement of letter knowledge. Table 3 shows the correct response rates of letter name knowledge and name writing. The improvement of both mean scores were statistically significant $(p<.001)$. Looking at the changes in the mean score from the descriptive statistics in the table, it was $67.9 \%$ during the pretest and $85 \%$ during the posttest. In the delayed posttest, it dropped somewhat but still remained high. Of note, is the name writing skill, which also showed progress in the four-month delayed test. Additionally, Table 3 also shows that the delayed test minimizes the standard deviation reducing variability in scores of both tests. This means the students' skills of letter recognition and name writing have improved. 
JALT2020

COMMUNITIES OF
TEACHERS \& IEARNERS

Table 3

Correct Response Rates of Letter Name Knowledge and Name Writing

\begin{tabular}{lccc}
\hline & Pretest (Apr.) & Posttest (Oct.) & Delayed (Mar.) \\
\hline Letter Name Knowledge & $67.93 \%$ & $85 \%$ & $83.97 \%$ \\
(SD) & $(23.09)$ & $(16,31)$ & $(13.91)$ \\
Name Writing & $58.62 \%$ & $81.38 \%$ & $87.59 \%$ \\
(SD) & $(35.93)$ & $(33.14)$ & $(25.86)$ \\
\hline
\end{tabular}

Effects of Phonology-Based Instruction on the Students' Attitude to Learn English

Regarding the research question 3, the students' responses in the questionnaire showed that the students were motivated to learn English. First, the students answered about the four macro skills of English using a Likert scale. Figure 7 shows that most of the students wanted to acquire all of the skills. The difference between pre- and postcourse questionnaire results were insignificant $(p>.05)$ as each mean score was high from the beginning.

Figure 7

What Skills I Want to Acquire

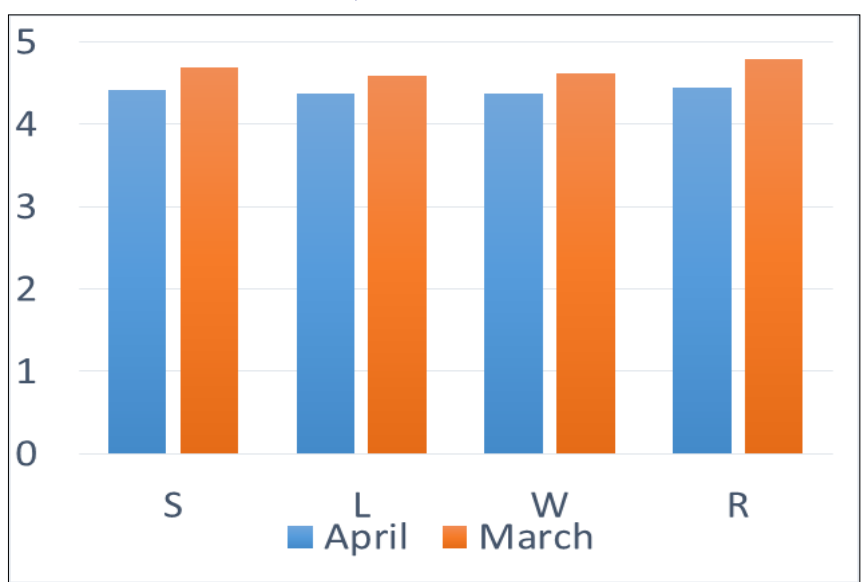

Table 4 demonstrates positive feedback from the students on phonology-based instruction. Many students mentioned Rhyme Time. Through recitation and singing along with nursery rhymes, the students gained confidence in their English-speaking skills. The feedback also revealed that the students were pleased to become better speakers of English. We can say that Rhyme Time contributed to the students' desire to speak English better, although the activity was originally aimed at promoting phonological awareness.

Table 4

Students' Comments Translated from Japanese

\begin{tabular}{|c|c|}
\hline $\begin{array}{l}\text { About Rhyme Time } \\
\text { (Nursery Rhyme) }\end{array}$ & $\begin{array}{l}\text { I can recite nursery rhymes better than before. } \\
\text { - I'm happy that I was able to say it better. } \\
\text { to read more English. } \\
\text { - I learned long lines of nursery rhymes as the rhythm of them } \\
\text { was so fun. }\end{array}$ \\
\hline $\begin{array}{l}\text { About Sound } \\
\text { Activities }\end{array}$ & $\begin{array}{l}\text { I can now hear English sounds better when playing sound } \\
\text { activities. } \\
\text { I found "k" was sometimes not pronounced when doing } \\
\text { "Snail Talk." I'm happy to be able to read English more than } \\
\text { ever. }\end{array}$ \\
\hline In General & - I enjoyed learning English. \\
\hline
\end{tabular}

The author and the ALT observed some effects on the students during the instruction. First, the students' attitude toward nursery rhymes grew more positive, and they enjoyed themselves. Second, the students' listening ability seemed to have improved. The progress of the students' pronunciation and participation could be observed in the video clips recorded in the classroom in July and November. Third, it was a good finding for the author that students felt English sounds and rhythms were fun even though they found some of them difficult. It may have happened because the students' phonological awareness had gradually developed, and they were actively trying to improve. Based on the findings from the assessment, and the observation, research question three can be answered affirmatively. 


\section{Students' Responses to Follow-Up Interviews}

Follow-up interviews were conducted with six students from the upper and lower groups according to the score of the post-tests. One girl from the upper group noted that in September she started to recognize which was the odd sound in sound activities. She added that she enjoyed various activities in English classes. One boy from the same group said that he enjoyed nursery rhymes and memorized some of them. The lower group included three boys who scored less than $40 \%$ in the sound categorization test. One boy noted that he started to notice difference while doing sound activities. Although he enjoyed letter activities, he recognized less than half of the lower-case letters. Another boy said that he really wanted to win the game called the key sound game. The other boy whose scores went up from 0\% to 30\% said that he wanted to be good at English, and sadly, was not good at recognizing letters. All three noted that they were happy when they were able to react correctly in the sound activities.

\section{Implications}

The findings from this research may suggest that phonology-based instruction to Japanese elementary school students is necessary. Based on these results, the best timing is thought to be before teaching phonics, reading and writing English. The following elements can be key to sustaining children's interest in English: multisensory input involving more than one sense that is helpful for learning English; meaningful activities that students find useful in their real lives; and something involving play, even at school.

\section{Conclusion}

The present study investigated the effectiveness of phonology-based instruction in the development of Japanese EFL elementary school fourth graders' phonological awareness. Despite the limitations that this is action research and there was no control group, this study demonstrated the teachability and learnability of phonological awareness for this group.

Regarding teachability, the results of the assessment indicates that phonologybased instruction was effective in improving students' phonological awareness and attitude toward learning English. Regarding learnability, the students exhibited signs demonstrating their motivation to learn English and enjoy various activities. As the results of the follow-up interviews indicate, students with low posttest scores also showed a positive attitude towards various activities in English. Additionally, as mentioned earlier, the fourth graders are entering a period when logic and reason are applied to learning (Inhelder \& Piaget, 1958), which may have helped the students to analytically recognize the phonological features of English. From these two perspectives, it could be reasonable to conclude that phonology-based instruction is effective in improving the pre-literacy skills of Japanese EFL fourth grade learners.

\section{Bio Data}

Naomi Watanabe is head English teacher at Higashi Elementary School, Tsukuba. After teaching English in junior high school for over 15 years, she began teaching in elementary school. By teaching English in both elementary and junior high schools, she became interested in phonological awareness. She earned her master's degree from Tsuda University in 2020 . Her research interests are related to early literacy.

\section{References}

Allen-Tamai, M. (1999). Phonological Awareness and reading ability of young Japanese EFL learners. TUJ Working Papers in Applied Linguistics, 14. TUJ. Retrieved from https://www.tuj.ac.jp/ tesol/publications/working-papers/vol-14/tamaiallen.html

Allen-Tamai, M. (2006). Alphabetical knowledge among Japanese young learners of English. Arcle review, 1, 72-81. Retrieved from https://www.arcle.jp/research/books/data/html/data/pdf/ vol1_4-2.pdf

Allen-Tamai, M. (2008). The relationship between alphabetical knowledge and phonological awareness among elementary school children. Arcle Review, 2, 112-123. Retrieved from https:// www.arcle.jp/research/books/data/html/data/pdf/vol2_5-1.pdf

Allen-Tamai, M. (2009). Literacy lessons for public elementary school children: How to develop alphabetical knowledge and phonological awareness. Arcle Review, 3, 26-42. Retrieved from https://www.arcle.jp/research/books/data/html/data/pdf/vol3_3-3.pdf

Allen-Tamai, M. (2010). Early literacy development of English phonological awareness and its relationship with alphabetical knowledge and word knowledge. Arcle Review, 4, 90-102. Retrieved from https://www.arcle.jp/research/books/data/html/data/pdf/vol4_5-2.pdf

Allen-Tamai, M. (2019). 小学校英語の文字指導 リタラシー指導の理論と実践[Early English literacy teaching in elementary school: theory and practice] (1st ed.). Tokyo Shoseki.

Chard, D. J., \& Dickson, S. V. (1999). Phonological awareness: Instructional and assessment guidelines. Intervention in School and Clinic, 34(5), 261-270. https://doi. org/10.1177/105345129903400502

Ehri, L. C., Nunes, S. R., Willows, D. M., Scuster, B. V., Yaghoub-Zadeh, Z., \& Shanahan, T. (2001). 


\section{JALT2020}

COMMUNITIES OF
TEACHERS \& IEARNERS
Phonemic awareness instruction helps children learn to read: Evidence from the National Reading Panel's meta-analysis. Reading Research Quarterly, 36(3) 250-287. https://doi.org/10.1598/ RRQ.36.3.2

Gillon, G. T. (2018). Phonological awareness: From research to practice (2nd ed.). Guilford Press. Ikeda, C. (2015). Introducing phonological awareness and early literacy instruction into Japanese elementary school English education: Its significance and feasibility (1st ed.). Kaitakusha.

Inhelder, B., \& Piaget, J. (1958). The growth of logical thinking from childhood to adolescence. Basic Book. http://dx.doi.org/10.1037/10034-000

Kirtley, C., Bryant, P., MacLean, M., \& Bradley, L. (1989). Rhyme, rime, and the onset of reading. Journal of Experimental Child Psychology, 48(2). 224-245. https://doi.org/10.1016/00220965(89)90004-0

MacLean, M., Bryant, P., \& Bradley, L. (1987). Rhymes, nursery rhymes, and reading in early childhood. Merrill-Palmer Quarterly, 33(3), 255-281. Retrieved from http://www.jstor.org/ stable/23086536

MEXT. (2017). 学習指導要領解説＼cjkstart外国語活動·外国語編 [The course of study for foreign language activity and foreign language] (1st ed.). Kairyudo.

Murakami, K. (2019). 目指せ!英語のユニバーサルデザイン授業一みんなにわかりやすい小・中学校の授業 づくり[Let's try a universal design class in English] (1st ed.). Gakken Plus.

Nation, I. S. P. (2009). Teaching ESL/EFL reading and writing (1st ed.). Routledge.

National Reading Panel (US), National Institute of Child Health, \& Human Development (US). (2000). Teaching children to read: An evidence-based assessment of the scientific research literature on reading and its implications for reading instruction: Reports of the subgroups. National Institute of Child Health and Human Development, National Institutes of Health. Retrieved from https:// www.nichd.nih.gov/sites/default/files/publications/pubs/nrp/Documents/report.pdf

Stahl, S. A., \& Murray, B. A. (1994). Defining phonological awareness and its relationship to early reading. Journal of Educational Psychology, 86(2), 221-234. https://doi.org/10.1037/00220663.86.2.221

Yopp, H. K., \& Yopp, R. H. (2009). Phonological awareness is child's play. Young Children, 64(1),

12-18. Retrieved from https://www.caligrafix.cl/files/investigaciones/Phonological-Awareness-isChilds-Play-Hallie-Kay-Yopp-Ruth-Helen-Yopp.pdf

Yopp, H. K., \& Yopp, R. H. (2011). Purposeful play for early childhood phonological awareness (1st ed.) Shell Education.

\section{Appendix A}

An Example of Elkonin Box Used in Class

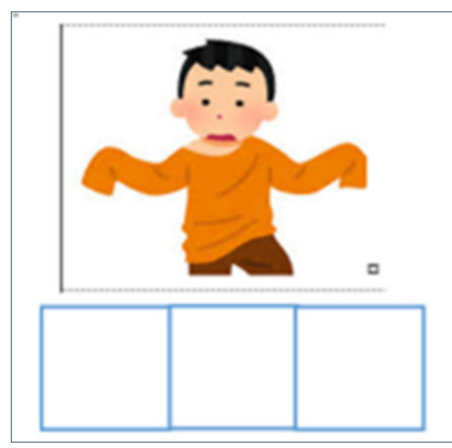

Appendix B

English Map

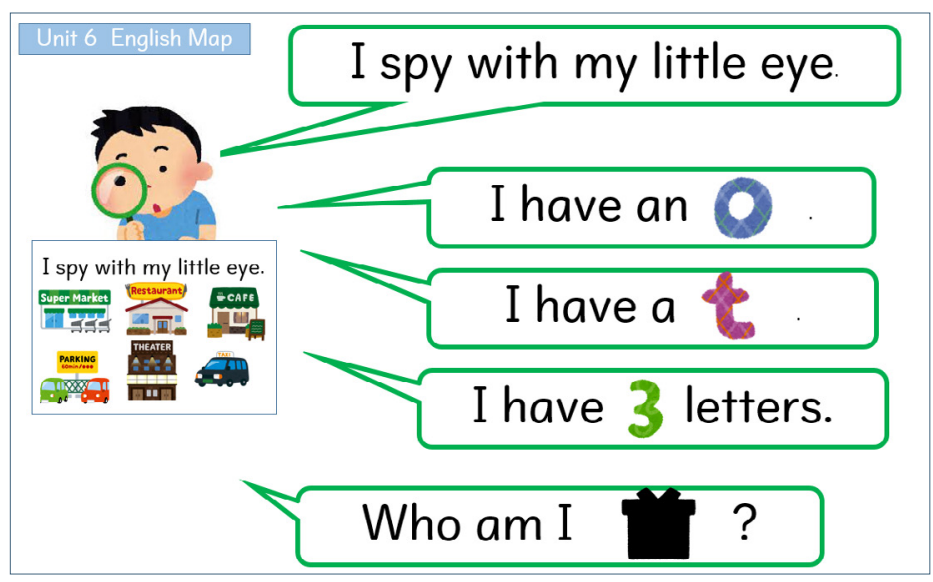

